\title{
LANGUAGE VARIATIONS FOUND IN THE NOVEL BUMI MANUSIA BY PRAMOEDYA ANANTA TOER
}

\author{
Agus Sulaeman \\ Universitas Muhammadiyah Tangerang \\ Sultanwahyu13@gmail.com \\ Abdul Rohim \\ Universitas Muhammadiyah Tangerang \\ Abdulrohim2013@yahoo.com \\ Zaenal Muttaqien \\ Universitas Muhammadiyah Tangerang \\ muttaqienzet@gmail.com
}

Sulaeman, A., Rohim, A. and Muttaqien, Z. (2020). Language variations found in the novel Bumi Manusia by Pramoedya Ananta Toer. Journal of English Language and literature, 5(1), 53-62. DOI 10.37110/jell.v5i01.95

Received: 05-01-2020

Accepted: 30-01-2020

Published:01-03-2020

\begin{abstract}
The purpose of this study describes the use of language variations found in the novel Bumi Manusia by Pramoedya Ananta Toer. The approach used in this study is a qualitative approach and the method used is a content analysis method that aims to provide an objective picture of language variations in accordance with the data contained in the novel Bumi Manusia by Pramoedya Ananta Toer. The data used in this study are written data in the form of novel texts containing language variations in the novel Bumi Manusia by Pramoedya Ananta Toer published by Mardi Yuana Printing Graphic Printing in 2015. Based on the analysis, there are variations in language in the novel Bumi Manusia by Pramoedya Ananta Toer namely: Dutch, Japanese, Javanese and English. In the novel Bumi Manusia, Dutch is a variation of language that dominates from other languages because in this novel it is told that there was a Dutchman in the Dutch East Indies. In the novel Bumi Manusia, Japanese is not very visible because Japanese is only a distraction in just one part. Javanese language can be said as a variation of language that dominates the two because in this novel tells the life of a genuine Javanese who falls in love with a Netherland. Same thing with the Javanese language in the novel Bumi Manusia, English is no less in existence with other language variations found in this novel. The significance of the study is to give useful information about the language variation and useful contribution for linguistic and education

Keywords: Language; Novel; Language Variation
\end{abstract}

\section{INTRODUCTION}

In modern times the position of literature is increasing and increasingly important. Literature not only provides inner pleasure and satisfaction, but also as a means of delivering moral messages to the public over social reality. Literary works created within a certain period of time can be mobilized about the circumstances and situations that occur during the creation of the literary works, both socio-cultural, religious, political, economic, and educational, besides that literary works can be used as socio-cultural documents that capture the reality of a certain period, but not a requirement that the created literary work is a reflection of the situation at the time the literary work was written.

Literary works are created because of the author's inner experience in the form of interesting world events or problems so that the idea of imagination that is expressed in written form and literary works will contribute to the figure values and order of the society's demands, this is a reciprocal bond between literature and society, although the literary work is fiction, but in reality, literature is also able to provide benefits in the form of moral values for its readers. Literature always presents a picture of life and life itself, 
which is a social reality. In this case, life will include relationships between people and individuals, between people, humans and God, and between events that occur in one's mind.

The novel is one of the containers in the spread of language variations or language variations in this study, researchers are interested in the novel entitled "Bumi Humans by Pramoedya Ananta Toer", research related to language variations. Such as the use of a combination of Indonesian with Dutch, and others contained in the novel.

The novel is one of the containers in the spread of language variations or language variations in this study, therefore the researchers are interested to analyze language variation in the novel entitled "Bumi Manusia" by Pramoedya Ananta Toer", because there are many combinations and language variations that exist in that novel, such as the use of a combination of Indonesian with Dutch, and others contained in the novel, then the reseachers use this problem as the background of the study

\section{Theoretical Foundation}

According to Nababan, sociolinguistics comes from the words "socio" and "linguistic". Sosio is the same as the social word which is related to the community. Linguistics is the study of and talking about language, especially the elements of language and between those elements. So, sociolinguistics is a study that arranges theories about the relationship between society and language. Based on the previous understanding, sociolinguistics also studies and discusses aspects of community language, especially the differences contained in language related to social factors.

Sociolinguistics not only learns about language but also learns about aspects of language used by society. Sociolinguistics is an interdisciplinary science between sociology and linguistics, two fields of empirical science that have close links. Sociology is an objective and scientific study of people in society, institutions, and social processes that exist in society. Sociology tries to find out how the community happened, is going on, and still exists. By studying institutions, social processes and all social problems in society, it will be known how humans adjust to their environment, how they socialize, and place themselves in their respective places in society. While linguistics is the field of science that studies language, or the science that takes language as the object of study. Thus it can be said that sociolinguistics is an interdisciplinary science that studies language in relation to the use of that language in society.

Sociolinguistics relates to the details of the actual use of language, such as the description of patterns of language use or certain dialects by the speaker, topic, setting. Sociolinguistics sees language first of all as a social system and a communication system as well as a part of a particular society and culture. Whereas what is meant by language use is a form of social interaction that occurs in concrete situations. Based on some of the descriptions above it can be concluded that sociolinguistics means learning about the language used in certain regions or certain dialects. Judging from the name, sociolinguistics involves sociology and linguistics, therefore sociolinguistics has a very close relationship with the two studies. Sosio is a society, and linguistics is the study of language. So the study of sociolinguistics is the study of language that is associated with social conditions. Based on some of the descriptions above, it can be concluded that sociolinguistics means the study of languages associated with certain societal conditions. Sociolinguistics tends to focus on social groups and linguistic variables used in that group while trying to correlate these variables with traditional demographic units in science social science, namely age, sex, socio-economic class, regional grouping, status and others.

Language is a medium to convey messages, ideas, ideas, and media for expression. According to Kridalaksana (2014: 32) "language is an arbitrary system of sound symbols used by members of social groups to work together, communicate, and identify themselves". Because of its arbitrary nature, each community group can make their own words or symbols according to their respective agreements. That is also why every community group, tribe or nation has their own language so that life becomes so beautiful. Javanese with Javanese, Balinese with Balinese, and Arabs with Arabic, English with English, and so on. You can imagine what would have happened if only all humans on earth had only one language. Language diversity turns out to have enriched the treasury of human life. It is estimated that currently in the world there are 6912 languages. There is a tendency from time to time that the numbers are decreasing, because many languages die alias there are no speakers.

The language we use is actually the same as the sound produced by animals. For example, 
p-ISSN 2540-8216, e-ISSN 2654-3745

https://journal.stibaiec-jakarta/ojs/index.php/jell when a cat meows, it is communicating with friends or the environment. Likewise, when a student shouts in front of the class, he is conveying something to his friends or people around him. Therefore, actually the sound of cats and students' screams is a form of communication, because both contain messages to be conveyed. But the sound of cats cannot be called language. While the students' screams are called languages. Therefore, it can be said that a cat sounds, while a student speaks.

Language variation is a kind of language variety whose use is adjusted to the function and situation, without ignoring the basic rules that apply in the language concerned. This is because, variations in language that occur as a result of social diversity and diversity of language functions. In terms of language variations there are two views. First, the variation is seen as a result of the social diversity of the speakers of that language and the diversity of functions of that language. Thus, language variations occur as a result of social diversity and diversity of language functions. Second, variations of the language already exist to fulfill its function as a means of interaction in diverse community activities. According to Chaer (2004: 62) language variation is the diversity of languages caused by the existence of social interaction activities carried out by people or groups that are very diverse and because of the speakers who are not homogeneous.

Novel is one of the literary works written by someone, to express all of his imagination through writing. The term novel comes from the Italian novella which means a small new item. Then, the word was interpreted as a literary work in the form of prose. The novel is an imaginative work that tells the whole side of the problematics of the life of a person or several figures. The novel is a fictional text that tells the long life of one or several people with various problems in it Kosasih (2019: 379). The novel presents the story of the twists and turns of a character's life, starting from the beginning of his life, from children / teenagers to adults. Then, the novel also marked changes in the fate of the characters themselves. For example, having a family, getting a job, and changing attitudes or beliefs.

With the length of the story stated in the novel, a lot of information can also be obtained in it. The information in question is certainly different from information normally obtained from letters, historical texts, articles, and other non-literary texts which are factual in nature. The information referred to in the form of the author's views about certain life values, such as the importance of religious beliefs, the importance of honesty, cooperation, and mutual respect for customs and culture.

\section{METHOD}

In this study using a qualitative approach to the content analysis research method. Research in any field always requires a main object. Literary research is a literary work with various genres such as poetry, novels, short stories, drama, and the like both originating from old / classical and modern literature. Various old literary genres that were the object of research covered all of their categories (Suleman, 2019: 247).

This research uses content analysis. the content method is related to the content of communication, both verbally, in the form of language and nonverbal which involves the content and communication messages in human life such as architecture, clothing, household appliances, and so on. Including social, political, economic issues, in the social sciences. But in literary works, the intended contents are the messages contained therein. Content in the content analysis method consists of two kinds, namely latent content and communication content. Latent content is the content that depends on documents and manuscripts, while the contents of communication are messages that are contained as a result of the communication that occurs. Latent content is as the author, while the content of communication, both verbally, in the form of language and nonverbal which concerns the content and communication messages in human life such as architecture, clothing, household equipment, and so on. Including social, political, economic problems in the social sciences. But in literary works, the intended content is the messages contained in it. Content in the content analysis method consists of two types, namely latent content and communication. Latent content is the content contained in documents and manuscripts, while the communication content is the message contained as a result of a communication tool that occurs. Latent content is as intended by the author, while the communication content is the content as manifested in the relationship with the script with consumers. In other words, the content of communication basically implies latent content, but not necessarily necessarily. The formal object 
of content analysis method is communication. Analysis of latent content will produce meaning, while analysis of communication content will produce meaning.

Relation to the research, the steps taken by the researcher are:

1. Read the whole novel.

2. Choose and determine the novel.

3. Marking words and groups of words that potentially contain variations in language.

4. Grouping words and groups of words based on variations in their respective languages.

5. Enter words and groups of words that contain language variations into the analysis table.

6. Analyzing the language variations contained in the novel.

Summing up the results of analysis of language variations

\section{Sources and Types of Research Data}

Data source is an action to get an information. Lofland argues that the main data sources in qualitative research are words, and actions, the rest are additional data such as documents and others. Related to this in this section the type of data is divided into words and actions, written data sources. If the researcher becomes an observer participating in a particular research setting, the activity will be utilized as much as possible depending on the atmosphere and circumstances encountered. According to Moeloeng basically qualitative research activities carried out consciously, directed and always aiming to obtain the necessary information (Sulaeman, 2019: 248).

In this case the source of research data is the source of the book Bumi Bumi by Pramoedya Ananta Toer and can be grouped into data as follows:

1. Primary data is data obtained directly from the main source. The primary data from this research is the book Bumi Bumi by Pramoedya Ananta Toer.
2. Secondary data in this study are data sourced from reference books relating to the object being the researcher.

\section{Data Collection Techniques}

Data collection techniques using documentation studies or literature studies, in this case a study of the novel Bumi Manusia by Pramoedya Ananta Toer. This novel is the main data source in research. Literature review is carried out with direct appreciation and understanding of meaning rationally. To do this, it can be developed through the documentation of study signs that serve as research instruments.

The documentation study technique is implemented in the following steps:

a. Researchers read critically the data sources in the novel Bumi Manusia by Pramoedya Ananta Toer. The reader carefully to understand the meaning contained in the data source.

b. Researchers read continuously and repeatedly the data sources in the novel Bumi Manusia by Pramoedya Ananta Toer.

c. Researchers read once again the source of the novel Bumi Manusia by Pramoedya Ananta Toer to mark the parts that were raised into data and analyzed further. This designation is adjusted to the data source.

\section{FINDING AND DISCUSSION \\ Research Findings}

Data collection is done by using the content analysis method. Researchers observe a literary work that is a novel. The selected sample is the novel Bumi Manusia. The reason for selecting these samples is because researchers are interested in the various languages in the novel Bumi Manusia. The analysis of language variations contained in the novel Bumi Manusia are as follows:

\begin{tabular}{|c|l|l|l|l|l|}
\hline \multirow{2}{*}{ No. } & \multicolumn{1}{|c|}{ Quote } & \multicolumn{3}{|c|}{ Language Variations } \\
\cline { 4 - 6 } & \multicolumn{1}{|c|}{$\begin{array}{l}\text { Japan } \\
\text { ese }\end{array}$} & $\begin{array}{l}\text { Javan } \\
\text { ese }\end{array}$ & English \\
\hline 1 & Aku tak suka pada sport (halaman 18) & & & & $\checkmark$ \\
\hline 2 & $\begin{array}{l}\text { Melongok melalui jendela aku lihat Mevrouw Télinga } \\
\text { melambai padaku (halaman19) }\end{array}$ & $\checkmark$ & & & \\
\hline 3 & Dokar dengan pér (halaman 20) & $\checkmark$ & & & \\
\hline 4 & $\begin{array}{l}\text { Dekat di belakang kayu terpasang papan nama besar dengan } \\
\text { tulisan : Boerderij Buitenzorg (halaman 24) }\end{array}$ & $\checkmark$ & & & \\
\hline 5 & Sekepal dan clurit (halaman 25) & & & $\checkmark$ & \\
\hline
\end{tabular}




\begin{tabular}{|c|c|c|c|c|c|}
\hline 6 & $\begin{array}{l}\text { Mengapa diam saja?" tegur Annelies dengan suara manis } \\
\text { dalam Belanda pergaulan (halaman 27) }\end{array}$ & $\checkmark$ & & & \\
\hline 7 & $\begin{array}{l}\text { Beberapa guruku yang kranjingan kata modern (halaman } \\
\text { 38) }\end{array}$ & & & $\checkmark$ & $\checkmark$ \\
\hline 8 & $\begin{array}{l}\text { Dan tumpukan-tumpukan réndéng yang telah siap (halaman } \\
\text { 48) }\end{array}$ & & & $\checkmark$ & \\
\hline 9 & $\begin{array}{l}\text { Mungkin bermaksud memakiku dengan kata monkey } \\
\text { (halaman 52) }\end{array}$ & & & & $\checkmark$ \\
\hline 10 & Kowé kira, sudah pake pakean Eropa, (halaman 64) & & & $\checkmark$ & \\
\hline 11 & "Mas!" (halaman 93) & & & $\checkmark$ & \\
\hline 12 & $\begin{array}{l}\text { Kalau ayahmu ternyata memang gila dan oleh Hukum } \\
\text { ditaruh onder curateele? (halaman 112) }\end{array}$ & $\checkmark$ & & & \\
\hline 13 & $\begin{array}{l}\text { Pada suatu hari aku dan Tuan dating ke Pengadilan untuk } \\
\text { mengakui Robert dan kau sebagai anak Tuan Mellema. } \\
\text { (halaman 136) }\end{array}$ & $\checkmark$ & & & \\
\hline 14 & $\begin{array}{l}\text { Ia tunjukkan padaku sebuah cerpen Een Buitengewoon } \\
\text { Gewoone Nyai die Ik ken (halaman 162) }\end{array}$ & $\checkmark$ & & & \\
\hline 15 & $\begin{array}{l}\text { Kantor mulai ramai: dokar, andong, pejalan kaki, penjaja, } \\
\text { pekerja (halaman 176) }\end{array}$ & & & $\checkmark$ & \\
\hline 16 & $\begin{array}{l}\text { "silahkan" katanya tiba-tiba dalam Jawa Kromo (halaman } \\
\text { 178) }\end{array}$ & & & $\checkmark$ & \\
\hline 17 & $\begin{array}{l}\text { Dengan menarik airmuka sengit ia bicara belanda } \\
\text { kepadaku: "Rupanya kesopanan pun sudah kau lupakan } \\
\text { maka tak segera sujud pada Bunda?" (halaman 187) }\end{array}$ & $\checkmark$ & & & \\
\hline 18 & $\begin{array}{l}\text { Aku bangun dan mengiringkannya, seorang siswa } \\
\text { S.I.B.A.(halaman 188) }\end{array}$ & $\checkmark$ & & & \\
\hline 19 & "tahu benar kau dia seorang Juffrouw?" (halaman 205) & $\checkmark$ & & & \\
\hline 20 & $\begin{array}{l}\text { "Max Havelaar atau De Koffieveillingen der } \\
\text { Nederlandsche Handelsmaatschappij" (halaman 209) }\end{array}$ & $\checkmark$ & & & \\
\hline 21 & $\begin{array}{l}\text { Mungkin pegawai pada kantor Majoor der Chineezen. } \\
\text { (halaman 224) }\end{array}$ & $\checkmark$ & & & \\
\hline 22 & Siapa tahu kelak kita bisa jadi éngko? (halaman 262) & $\checkmark$ & & & \\
\hline 23 & $\begin{array}{l}\text { Cuma sayang sekali Nederland belum membenarkan } \\
\text { seorang wanita jadi anggota Tweede Kamer. (halaman 288) }\end{array}$ & $\checkmark$ & & & \\
\hline 24 & $\begin{array}{l}\text { Judulnya: Uit bet schoone Leven van een mooie Boerin. } \\
\text { Pengarangnya bernama: Max Tollenaar. (halaman } 316 \text { ) }\end{array}$ & $\checkmark$ & & & \\
\hline 25 & $\begin{array}{l}\text { Dia dan mereka itu, biarpun berbicara Afrikan (halaman } \\
\text { 327) }\end{array}$ & $\checkmark$ & & & \\
\hline 26 & $\begin{array}{l}\text { Dan bangsa Slameier tak lain dari keturunan Pribumi Jawa } \\
\text { dan Bugis-Makassar-Madura (halaman 327) }\end{array}$ & $\checkmark$ & & & \\
\hline 27 & $\begin{array}{l}\text { "Tuanku kurang tertarik, kecuali tulisan orang-orang } \\
\text { Vlaam" (halaman 344-345) }\end{array}$ & $\checkmark$ & & & \\
\hline 28 & $\begin{array}{l}\text { Selama ini ia jadi pengagumku dan menganggap aku } \\
\text { sebagai Mei-Kind (hlmalaman 365) }\end{array}$ & $\checkmark$ & & & \\
\hline 29 & Orang-orang gila dan kriminil (halaman 392) & $\checkmark$ & & & \\
\hline 30 & Beberapa pikar kertas juga bergelantungan (halaman 401) & & $\checkmark$ & & \\
\hline 31 & $\begin{array}{l}\text { Ia juga akan menghadap tuan Direktur Onderwijs, } \\
\text { Nijverheid en Eeredienst. (halaman 434) }\end{array}$ & $\checkmark$ & & & \\
\hline 32 & $\begin{array}{l}\text { "Ya. Dan lebih dari itu tak pernah merasa senang bernama } \\
\text { Dapperste. (halaman 454) }\end{array}$ & $\checkmark$ & & & \\
\hline 33 & $\begin{array}{l}\text { Bahkan orang mengubah Dapperste jadi Lafste (halaman } \\
\text { 454) }\end{array}$ & $\checkmark$ & & & \\
\hline 34 & $\begin{array}{l}\text { "negeri-negeri akan berperang habis-habisanuntuk } \\
\text { mendapatkan putri seperti menantuku, mbedah praja } \\
\text { mboyong putri. (halaman } 457 \text { ) }\end{array}$ & & & $\checkmark$ & \\
\hline 35 & $\begin{array}{l}\text { "Stt. Diam, kau. Jadi kau larang istrimu dipangur?" } \\
\text { (halaman 459) }\end{array}$ & & & $\checkmark$ & \\
\hline
\end{tabular}




\begin{tabular}{|c|l|l|l|l|l|}
\hline 36 & $\begin{array}{l}\text { Padaku sendiri dating seorang Indo, mengaku bekas } \\
\text { Vaandrig. (halaman 481) }\end{array}$ & $\checkmark$ & & \\
\hline 37 & Melalui adcokatnya Tuan Mr Hans Graeg (halaman 485) & $\checkmark$ & & & \\
\hline 38 & Juga yang dikehendaki S.D.A.P. (halaman 495) & $\checkmark$ & & & \\
\hline 39 & $\begin{array}{l}\text { Sejauh yang pernah diajarkan dalam Nederlandsch- } \\
\text { Indische Geschiedenis (halaman 507) }\end{array}$ & $\checkmark$ & & & \\
\hline 40 & $\begin{array}{l}\text { Satu pasukan Maresosé, baru menyelesaikan latihan di } \\
\text { Malang (halaman 513) }\end{array}$ & $\checkmark$ & & & \\
\hline
\end{tabular}

\section{Discussion}

From the analysis data above, it can be described as follows:

\section{Dutch}

In the novel Bumi Manusia, Dutch is a variation of language that dominates from other languages because in the novel Bumi Manusia it is said that there is a Dutchman in Hindi-Dutch.

In this novel there is Dutch in several quotations that are influenced by Dutch, including:

Looking through the window I saw Mevrouw Télinga waving at me (page 19)

In the quote Mevrouw means mistress and Télinga (Teelingkha) in Dutch, it means that the ear is a variation of language which at that time was influenced by Dutch.

1) Dokar with pér, in the quote pér which means per (spring) is a variation of language which was influenced by the Dutch language.

2) Near the back of the wood a large nameplate is attached with the words: Boerderij Buitenzorg,in the quote Boerderij Buitenzorg which means that agricultural companies are variations of language which at that time were influenced by Dutch.

3) Why don't you say anything? "Annelies said in a sweet voice in Dutch interaction, translated in Dutch to mean waarom zwijg je?

4) If your father turns out to be crazy and by the law put onder curateele?, on the quote onder curateele which means that under forgiveness is a variation of language which at that time was influenced by Dutch.

5) One day you and I came to court to acknowledge Robert and you as Mr. Mellema's son, which in Dutch means erkennen, that is, a blood child is erkend natuurlijk.

6) $\mathrm{He}$ showed me a short story Een Buitengewoon Gewoone Nyai die Ik ken, in the quote Een Buitengewoon Gewoone
Nyai die Ik ken which means an extraordinary ordinary hijack that I know is a language variation that was influenced by Dutch.

7) By drawing a fierce expression he spoke to the Dutch to me: "Apparently politeness have you forgotten, then do not immediately bow down to Mother?", Translated in Dutch means blijkbaar beleefdheid ben je vergeten, buig je and niet meteen voor Moeder? (Google translation)

8) I wake up and accompany him, a student of S.I.B.A., S.I.B.A. (School voor Inlandsche Bestuurs Ambtenaren) in the quote S.I.B.A. in Dutch means the School for Prospective Officers of the Pangreh Praja Prija is a variety of languages which at that time was influenced by the presence of Dutch.

9) "Mr. Regent, you are happy, sir. Not only the Dutch, especially the attitude "and back in the Netherlands, translated in Dutch is Meneer Regent, $\mathrm{u}$ bent gelukkig, mijnheer. Niet alleen de Nederlanders, vooral zijn houding (google translate)

10) "Do you really know that he is a Juffrouw?", In the quote Juffrouw which means "miss" is a variation of language which was influenced by the Dutch language.

11) "Max Havelaar or De Koffieveillingen der Nederlandsche Handelsmaatschappij", in this quote Max Havelaar or De Koffieveillingen der Nederlandsche Handelsmaatschappij which means that coffee is a variation of language which was influenced by Dutch.

12) Maybe the employees at the Majoor der Chineezen office, in the quote Majoor der Chineezen, which means that the Chinese community leaders were given a military rank in a place, is a variation of language which was influenced by Dutch. 
13) Who knows that someday we could be a cranky ?, in the quote éngko (en compagnie) which means allies are variations of language which at that time were influenced by the presence of Dutch.

14) Only the Netherlands has not yet confirmed that a woman is a member of Tweede Kamer, in that quote Tweede Kamer, which means the lower house or people's representatives is a variation of language which was influenced by Dutch.

15) The title: Uit bet schoone Leven van een mooie Boerin. The author's name is: Max Tollenaar, in that quote Uit bet schoone Leven van een mooie Boerin which means from the beautiful life of a beautiful farmer woman is a variation of language which was influenced by Dutch.

16) He and they, even though speaking Afrikan, in this quotation Afrikan can be interpreted as the tongue of South Africa is a variation of language which at that time was influenced by the presence of Dutch.

17) And the Slameier people are none other than Javanese and Bugis-MakassarMadurese descendants, in the quote Slameier which means the African naming for Indies Indies who were banished by the Company to South Africa, in general the Muslim religion is a variation of language which at that time was influenced by the language Netherlands.

18) "My lord is less interested, except for the writings of the Vlaam people", in this quotation Vlaam means that South Holland joined Belgium and being the northern part of Belgium was a variation of languages which at that time was influenced by Dutch.

19) During this time he became my admirer and regarded me as Mei-Kind, in the quote Mei-Kind which means a child in May or can be said to be a child of luck is a variation of language which was influenced by the presence of Dutch.

20) People who are crazy and criminal (crimineel), on the quote criminal has the meaning of a villain, usually in big things. This word became the preferred designation in the discussions of the time, a variety of languages which at that time were influenced by Dutch.
p-ISSN 2540-8216, e-ISSN 2654-3745

https://journal.stibaiec-jakarta/ojs/index.php/jell

21) He will also appear before Mr. Onderwijs Director, Nijverheid en Eeredienst, on the quote

22) Onderwijs, Nijverheid en Eeredienst means the Department of Teaching, Crafts and Worship is a language variation that was influenced by Dutch.

23) "Yes. And more than that never felt happy named Dapperste, in the quote Dapperste has a bold meaning which is a variation of the language which at that time was influenced by the existence of Dutch.

24) In fact, people changed Dapperste to Lafste, in that quote Lafste, which means the whipped, is a variation of language which was influenced by the Dutch language.

25) I myself come from an Indo, claiming to be a former Vaandrig, in that quote Vaandrig means young lieutenant is a variation of language which at that time was influenced by the presence of Dutch.

26) Through his adocate Mr. Mr. Hans Graeg, Mr. (Meester in de Rechten) in the quote $\mathrm{Mr}$.

which means a small degree of okum is a variation of language which at that time was influenced by the presence of Dutch. Also desired by S.D.A.P., S.D.A.P (Social-Democracy Arbeiderspartij), in the quote. S.D.A.P. Social Democratic Labor Party is a variation of language which was influenced by the presence of Dutch.

27) As far as has been taught in the Nederlandsch-Indische Geschiedenis, the quotation

Nederlandsch-Indische Geschiedenis means the History of the Dutch East Indies is a variation of the language which at that time was influenced by Dutch.

28) One Maresosé (marechaussee), having just finished training in Malang, in this quote

Maresosé means the Dutch East Indies Army Combat Troops, established near the close of the 19th century to suppress riots, especially in Aceh, is a variation of language which was influenced by Dutch.

\section{Japanese}

In the novel Bumi Manusia, Japanese is not very visible because Japanese is only a distraction in just one part. In this novel there is Japanese in 
several quotes that are influenced by Japanese, including:Some paper pikemono (kakemono) also hang, on the quote pikar which means painting on paper or cloth is a variation of language which at that time was influenced by Japanese because the Japanese state began to enter and colonize Indonesia.

\section{Javanese}

Javanese language can be said as a variation of language that dominates the two because in this novel tells about the life of a genuine Javanese who falls in love with a Netherland.

In this novel there is Javanese in several quotations that are influenced by Javanese, including:

1) Sekepal and clurit, in the quotation clurit which means big arit (traditional Madurese weapon)

is a variation of language which at that time was influenced by the existence of Madurese Javanese.

2) Some of my teachers who are modern kranjingan, in the quote kranjingan which means

possessed / insolent or can also be said to be crazy, is a variation of language which was influenced by the presence of coarse Javanese.

3) And the ready piles of réndéng, in the quote réndéng which means the leaves and stems of peanuts are variations of the language which at that time was influenced by the presence of Javanese.

4) Kowé guess, already using European use, in the quote Kowé which means you are a variety of languages which at that time was influenced by Javanese language with a geographical location in the middle so that the language is not smooth or not rude.

5) "Mas!", In the mutations, Mas, which means the nickname for older brothers is a variation of language which at that time was influenced by Javanese.

6) The office is getting busy: dokar, carriage, pedestrians, peddlers, workers, the quotation of dokar and andong can be interpreted as vehicles that use horses which are variations of language which at that time were influenced by Javanese.

7) "please" he said suddenly in Javanese Kromo, which in Javanese Kromo means Monggo is a variation of language which at that time was influenced by the presence of Javanese Kromo (smooth / polite).

8) "countries going to war to the point of getting daughters like my daughter-inlaw, mboyong prajab daughter, on this quote it can be interpreted that mboyong prajna daughter dissecting the honor of servants is a variation of language which at that time was influenced by Javanese.

9) "Stt. Shut up. So you forbid your wife to be unemployed?", The quotation is called which means to cut and spread teeth is a variation of language which at that time was influenced by Javanese.

\section{English}

Similar to the Javanese language, in the novel Bumi Manusia, the English language is no less inferior to the variations of other languages in this novel.

In this novel there is English in several quotes that are influenced by English, including:

1) I don't like sports, in that quote sport which means sports is a variation of language which at that time was influenced by English because English is an international language.

2) Some of the teachers who have modern word kranjingan, in the quote can be interpreted as modern, are variations of the language which at that time were influenced by the presence of English because English is an international language.

3) Probably intended to curse me with the word monkey, which means monkey is a variation of language which was influenced by the presence of English to make ridicule as if it does not directly make the person offended (if in Indonesia).

Language variation that exist in this novel will vary and has different view and function. It can be seen as a result of the social diversity of the speakers of that language and the diversity of functions of that language that occur as a result of social diversity and diversity of language functions. And language variation occur when the existence of social interaction activities carried out by people or groups that are very diverse. 
Journal of English Language and literature

Volume 5, Issue 1,March 2020

\section{CONCLUSION}

Language variation is a kind of language variety whose use is adjusted to the function and situation, without ignoring the basic rules that apply in the language concerned. This is because, variations in language that occur as a result of social diversity and diversity of language functions. In terms of language variations there are two views. First, the variation is seen as a result of the social diversity of the speakers of that language and the diversity of functions of that language. Thus, language variations occur as a result of social diversity and diversity of language functions. Second, variations of the language already exist to fulfill its function as a means of interaction in diverse community activities.

\section{REFERENCES}

Abdul, C . (2003). Linguistik Umum. Jakarta : PT RINEKA CIPTA

Aminuddin. (2015). Pengantar Apresiasi Karya Sastra. Bandung: Sinar Baru Algensindo.

Aziez, F and Abdul, H. (2015). Menganalisis Fiksi Sebuah Pengantar Jakarta: Ghalia Indonesia.

Bahtiar, A and Aswinarko. (2013). Metode Penelitian Sastra. Tangerang: Pustaka Mandiri.

Chaer, A. (2014). Linguistik Umum. Jakarta: Eineka Cipta.

Endraswara, S. (2011). Metodologi Penelitian Sosiologi Sastra. Yogyakarta: CAPS.

Kosasih and Kurniawan, E. (2019). 22 Jenis Teks dan Strategi Pembelajarannya di $S M A-M A / S M K$. Bandung: Yrama Widya.

Lumintaintang, Y.B.M. (2009). Permasalahan Berbahasa. dalam Rubrik Bahasa [online].
p-ISSN 2540-8216, e-ISSN 2654-3745

https://journal.stibaiec-jakarta/ojs/index.php/jell

Based on the results of the analysis, there are variations in language in the novel Bumi Manusia by Pramoedya Ananta Toer namely: Dutch, Japanese, Javanese and English. In the novel Bumi Manusia, Dutch language is a language variation that dominates over other languages because in this novel there is a Dutchman who is told in the Dutch East Indies. In the novel Bumi Manusia, Japanese is not very visible because Japanese is only a distraction in just one part. Javanese language can be said as a variation of language that dominates the two because in this novel tells the life of a genuine Javanese who falls in love with a Netherland. The same is true of Javanese in the novel Bumi Manusia, English is no less in existence with other language variations found in this novel.

https://rubrikbahasa.wordpress.com/2009/ 06/30/permasalahan-berbahasa/.

Sulaeman, A and Ghoziyah. (2019). Metodologi Penelitian Bahasa dan Sastra. Edu pustaka. Jakarta.

Sulaeman, Mutoharoh, Goziyah. (2018). Interferensi Morfologi Bahasa Thailand Kedalam Bahasa Indonesia. Tangerang : PBSI FKIP UMT.

Toer, P A.(2015). Bumi Manusia.Bogor: Percetakan Grafika Mardi Yuana

Tarigan, H.G. (2015). Prinsip Dasar Sastra. Bandung: Angkasa.

Teeuw. (2015). Sastra dan Ilmu Sastra. Bandung: Dunia Pustaka Jaya.

Waridah. (2015). Penggunaan Bahasadan Variasi Bahasa dalam Berbahasadan Berbudaya. Jurnal Simbolika / Volume 1 / Nomor 1 / April 2015. https://www.google.com/search?client=fir efox-b$\underline{\mathrm{d} \& \mathrm{q}=\mathrm{JURNAL}+\mathrm{VARIASI}+\mathrm{BAHASA}}$ 
Agus Sulaeman, Abdul Rohim and Zaenal Muttaqien

Language variations found in the novel bumi manusia by Pramoedya Ananta Toer 